\title{
Assessment of the efficacy of primary percutaneous coronary intervention in patients with ST-segment elevation myocardial infarction based on the ECG analysis
}

Ocena skuteczności leczenia pierwotną angioplastyką wieńcową chorych z ostrym zawałem serca z przetrwałym uniesieniem odcinka ST na podstawie analizy krzywej EKG

\author{
Hikmat H. Madżitow, Donyor A. Alimow \\ Republican Research Center of Emergency Medicine of Uzbekistan Republic Ministry of Health, Uzbekistan Republic
}

Post Kardiol Interw 2011; 7, 4 (26): 292-296

DOI: $10.5114 /$ pwki.2011.25787

\begin{abstract}
Background: The method of recording ECG is of particular importance for the diagnosis of cardiac arrhythmias, and an analysis of ST-segment behaviour, providing valuable information for the assessment of coronary circulation and the prognosis of patients with acute coronary syndrome.

Aim: The objective of our study was to evaluate the effectiveness of reperfusion therapy with primary revascularization of the coronary artery responsible for myocardial infarction (infarct-related artery, IRA) in patients with acute myocardial infarction (AMI) with persistent ST-segment elevation in intraoperative ECG monitoring.

Material and methods: The study included 72 patients (64-89\% men) with anterior AMI who were hospitalized in order to perform primary angioplasty (primary PCI).

Results: The average time from onset of pain to admission to hospital was $2.5 \pm 1.3 \mathrm{~h}$. The average time from admission to start of treatment (pPCl) was $78.2 \pm 12.4$ min. Effective treatment with primary PCI IRA stenting was performed in all 72 patients (100\%) after initial recanalization and predilation. All patients achieved good angiographic results evaluated on the basis of the size of the residual stenosis (below 10\%), while flow in the grade TIMI III was found in 62 (86.1\%) treated patients. In 49 patients (68\%) metal stents ("Chopin") were implanted, and in 23 (32\%) other patients paclitaxel-eluting stents ("Luc-Chopin") (Balton, Warsaw, PL) were implanted. ECG recording including the nature and frequency of arrhythmia was initiated prior to PCl. The measurements of changes in ST-segment elevation in relation to the isoelectric line were evaluated in the lead that best maps the changes in recording. Analysis of ECG monitoring results showed the characteristic dynamics of reduction of the ST level. Index rate of ST-segment depression after PCI was $3070.3 \pm 946.6 \mu \mathrm{V} / \mathrm{h}$. In all cases with PCI there was reported the occurrence of arrhythmias after the reperfusion. Ventricular extrasystole (ExV) occurred in 72 patients (100\%), accelerated idioventricular rhythm in 13 (18.0\%), ventricular tachycardia in 14 (19.4)\%, and ventricular fibrillation in 2 (2.7\%). Through correlation analysis a significant association was detected between indicators of the speed of ST-segment depression after reperfusion, and left ventricular ejection fraction (LVEF), calculated 7 days after $\mathrm{PCI}(r=0.53366, p<0.001)$.

Conclusions: 1) ECG monitoring is a study method of high clinical value, to evaluate the efficacy of reperfusion therapy in patients with AMI. 2) A significant correlation was detected between the rate of ST-segment depression after reperfusion and LVEF measured after 7 days of ACS with ST-segment elevation. 3) Index of ST-segment depression after reperfusion is a good predictor of restoration of left ventricular systolic function. 4) Primary PCI with stenting is an effective method of IRA reperfusion treatment of patients with AMI.
\end{abstract}

Key words: myocardial infraction, ST elevation, percutaneous transluminal coronary angioplasty, stenting, reperfusion, electrocardiography

\section{Streszczenie}

Wprowadzenie: Metoda rejestracji zapisu krzywej EKG ma szczególne znaczenie dla diagnostyki zaburzeń rytmu serca oraz analizy zachowania się odcinka ST, dostarcza bowiem cennych informacji istotnych dla oceny stanu krążenia wieńcowego oraz rokowania chorego z ostrym zespołem wieńcowym (OZW).

Cel: Ocena skuteczności leczenia reperfuzyjnego za pomocą pierwotnej rewaskularyzacji tętnicy odpowiedzialnej za zawał serca (ang. infarct related artery, IRA) u chorych z ostrym zawałem serca z przetrwałym uniesieniem odcinka ST (ang. acute myocardial infarction, AMI) na podstawie śródzabiegowego monitorowania krzywej zapisu EKG.

Corresponding author/Adres do korespondencji:

Madżitow Hikmat Chamidowicz MD, PhD, M. Babajewa St., cottage 1a, Taszkient, Republic of Uzbekistan, e-mail: hikmat1968@yahoo.com Praca wpłynęła: 14.06.2011, wersja poprawiona: 23.09.2011, przyjęta do druku: 30.09.2011. 
Materiał i metody: Badaniem objęto 72 chorych [64 (89\%) mężczyzn] z AMI ściany przedniej, którzy zostali hospitalizowani w celu wykonania pierwotnej angioplastyki wieńcowej (ang. primary percutaneous coronary intervention, $\mathrm{pPCl}$ ).

Wyniki: Średni czas od początku dolegliwości bólowych do chwili przyjęcia chorych do Kliniki wynosił 2,5 $\pm 1,3$ godziny, natomiast średni czas od chwili przyjęcia do rozpoczęcia zabiegu pPCI 78,2 $\pm 12,4$ minuty. Skuteczny zabieg pPCI ze stentowaniem IRA wykonano u wszystkich 72 chorych (100\%) po wstępnej rekanalizacji i predylatacji. U wszystkich osób osiągnięto dobry wynik angiograficzny oceniany na podstawie wielkości rezydualnego zwężenia (poniżej 10\%), natomiast przepływ TIMI 3 stwierdzono u 62 (86,1\%) spośród leczonych chorych. U 49 chorych (68\%) wszczepiono metalowe stenty Chopin, a u 23 pozostałych chorym (32\%) - stenty uwalniające paklitaksel Luc-Chopin (Balton, Warszawa). Rejestrację krzywej EKG, w tym pod kątem charakteru i częstości zaburzeń rytmu, rozpoczynano przed zabiegiem PCI, przy czym pomiary zmian uniesienia odcinka ST w stosunku do linii izoelektrycznej oceniano w odprowadzeniu najlepiej odwzorowującym zmiany zapisu. Analiza wyników monitorowania EKG wykazała charakterystyczną dynamikę obniżenia odcinka ST. Wskaźnik szybkości obniżenia odcinka ST po PCI wyniósł 3070,3 $\pm 946,6 \mu \mathrm{V} / \mathrm{h}$. We wszystkich przypadkach PCl odnotowano wystąpienie reperfuzyjnych zaburzeń rytmu. Ekstrasystolia komorowa wystąpiła u 72 chorych (100\%), przyspieszony rytm idiowentrykularny - u 13 (18,0\%), tachykardia komorowa - u $14(19,4) \%$, a migotanie komór- u 2 (2,7\%). Dzięki analizie korelacji wykryto istotny związek pomiędzy wskaźnikami szybkości obniżenia odcinka ST po reperfuzji oraz frakcji wyrzutowej lewej komory obliczanej w 7. dniu po $\mathrm{PCl}(r=0,53366, p<0,001)$.

Wnioski: 1) Monitorowanie zapisu EKG jest metodą badania o bardzo dużej wartości klinicznej, pozwalającą ocenić skuteczność leczenia reperfuzyjnego osób z AMI. 2) Wykryto istotne korelacje między szybkością obniżenia odcinka ST po reperfuzji i frakcją wyrzutową lewej komory zmierzoną w 7. dniu OZW z uniesieniem odcinka ST. 3) Wskaźnik szybkości obniżenia odcinka ST po reperfuzji jest dobrym predyktorem stopnia przywrócenia funkcji skurczowej lewej komory. 4) Pierwotna angioplastyka wieńcowa ze stentowaniem IRA stanowi skuteczną metodę reperfuzyjnego leczenia osób z AMI.

Słowa kluczowe: zawał serca, uniesienie odcinka ST, przezskóna angioplastyka wieńcowa, implantacja stentu, reperfuzja, badanie elektrokardiograficzne

\section{Introduction}

Rapid restoration of the blood flow in the coronary artery occluded by thrombus is a cornerstone of treatment in patients with ST-segment elevation myocardial infarction (STEMI). Atherosclerosis is a long-lasting process consisting of progressive myocardial injury with velocity depending on the status of circulation in the particular area and around that area [1].

Results obtained in numerous angiographic studies concerning strict relation between the patency of the infarct related artery (IRA) and the evolution of myocardial infarction after reperfusion confirmed the open artery hypothesis introduced by Braunwald in 1989 [2]. According to that hypothesis, early restoration of flow in the IRA has a direct impact on the size of myocardial necrosis, on the left ventricular function and therefore on the risk of early and late mortality [3].

Restoration and maintenance of patency of the coronary artery whose occlusion led to ST-segment elevation myocardial infarction is obtained with means of thrombolysis and percutaneous coronary intervention. However, the latter method is characterized by a better efficacy defined by early and long-term results [4].

Widespread use of these methods in clinical practice required introduction of reliable and most likely non-invasive methods assessing the efficacy of treatment and prediction of the treatment results. The ECG registration has a great value for the diagnosis of arrhythmia and ST-segment changes and provides important information on the status of coronary circulation and patient prognosis [5].

\section{Aim}

The aim of the study was to assess the efficacy of reperfusion obtained by means of primary percutaneous coronary intervention of the IRA in patients with STsegment elevation myocardial infarction based on intraprocedural ECG monitoring.

\section{Material and methods}

The study included 72 patients (64 men - 89\%) with anterior STEMI admitted to the Department of Cardiologic Reanimation, Republican Research Center of Emergency Medicine of Uzbekistan Republic Ministry of Health.

The mean time between the onset of pain and admission to the Department was $2.5 \pm 1.3 \mathrm{~h}$. The mean time between the admission and beginning of the percutaneous coronary intervention was $78.2 \pm 12.4 \mathrm{~min}$.

The study excluded patients with a history of myocardial infarction, congestive heart failure, acute abnormalities of the cerebral circulation or left bundle branch block on ECG. Clinical characteristics of patients included in the study are presented in Table 1.

Selective coronary angiography and percutaneous coronary interventions $(\mathrm{PCl})$ were performed in an operating room equipped with an X-ray system (Integris Allura FD 20. Philips). The PCI with stent implantation was an "ad hoc" procedure performed directly after diagnostic coronary angiography. Successful PCI procedure with stenting of the IRA was performed in all 72 patients (100\%) after initial recanalization and pre-dilation. Good angiographic result of the procedure defined as residual stenosis $<10 \%$ was obtained in all patients. TIMI 3 flow was achieved in 62 patients (86.1\%). Forty-nine patients (68\%) received bare metal "Chopin" stents and the remaining 23 patients (32\%) underwent implantation of paclitaxel-eluting "Luc-Chopin" stents (Balton, Warsaw, PL).

The ECG registration in patients included in the study was performed using the following devices: DatexOhmeda (Finland), Philips IntelliVue MP20 and subse- 
Table 1. Clinical characteristics of patients

Tabela 1. Charakterystyka kliniczna chorych

\begin{tabular}{lcc}
\multirow{2}{*}{ Parameter } & \multicolumn{2}{c}{ Number of patients } \\
\cline { 2 - 3 } & $n$ & $\%$ \\
\hline Patients (\%) & 72 & 100 \\
\hline Age (M \pm SD) [years] & $48 \pm 9.8$ \\
\hline Sex, male & 64 & 88.8 \\
\hline Angina & 40 & 55.5 \\
\hline Hypertension & 30 & 41.6 \\
\hline Diabetes mellitus & 15 & 20.8 \\
\hline Smoking & 57 & 79.1 \\
\hline Hypercholesterolaemia & 55 & 76.4
\end{tabular}

quently in the hospital room with the Shiller MT-200 device (Switzerland).

The ECG registration with monitoring of the character and frequency of arrhythmia began before the $\mathrm{PCl}$. Measurement of the ST-segment changes in relation to the isoelectric line was assessed in the lead with the most pronounced changes. Assessment was performed $60 \mathrm{~ms}$ after the J point using the TP segment as the reference (calibration $0.1 \mathrm{mV} / 1 \mathrm{~mm}$ ). The analysis included the altitude of the ST segment elevation in relation to the isoelectric line (maximal single lead residual ST elevation - maxSTE) and the velocity of ST-segment resolution after reperfusion. The latter parameter was calculated after determination of the difference between maximal and minimal value on the ST-segment dynamic trend in microvolts $(\mu \mathrm{V})$ in relation to time $(\mu \mathrm{V} / \mathrm{h})$.

Echocardiography was performed on the SonolineOmnia machine (Siemens) equipped with a $4.0 \mathrm{MHz}$ frequency head according to the standard methodology recommended by the American Echocardiographic Society 1,3 and 7 days after infarction. Left ventricular enddiastolic volume (EDV) and end-systolic volume (ESV) as well as left ventricular ejection fraction (EF) were calculated in B-mode presentation according to the commonly used equation.

The scheme of antiplatelet treatment was based on the multicenter studies CURE-PCI and CREDO according to which all patients received acetylsalicylic acid (first dose of $300 \mathrm{mg}$ and $75 \mathrm{mg} /$ day thereafter) and clopidogrel - one dose of $300 \mathrm{mg} 6 \mathrm{~h}$ before or $600 \mathrm{mg} 2 \mathrm{~h}$ before $\mathrm{PCl}$ and $75 \mathrm{mg}$ daily thereafter.

\section{Statistical analysis}

Statistical analysis was performed using the EXCEL 7.0 worksheet and STATISTICA 6.0 software for WINDOWS. All parameters were presented as the arithmetic mean (M), standard deviation (SD) or median (Me) for parameters without normal distribution. Normality of data distribution was assessed by means of the Kolmogorov test. To analyse the correlation between the analysed parameters the linear Pearson correlation coefficient was calculated.

\section{Results}

Total occlusion (TIMI flow 0 ) of the left anterior descending artery (LAD) was confirmed in all 72 patients. The occlusion was localized in the proximal LAD segment in 49 patients $(68 \%)$ and in the median LAD segment in 23 patients (32\%). All patients underwent a successful PCI procedure with LAD stenting. TIMI flow 3 was restored in 62 patients (86.1\%) and TIMI flow 2 in 10 patients (13.9\%). There were no deaths or complications in the form of instent thrombosis or distal embolization.

Analysis of the results of ECG monitoring showed characteristic dynamics of ST segment resolution. The index of ST-segment resolution velocity after PCI was $3070.3 \pm 946.6$ $\mu \mathrm{V} / \mathrm{h}$. Arrhythmia from reperfusion was noted in all cases of $\mathrm{PCI}$. Ventricular extrasystole (VE) occurred in 72 patients (100\%), accelerated idioventricular rhythm (AIVR) in 13 patients (18\%), ventricular tachycardia (VT) in 14 patients (19.4\%) and ventricular fibrillation (VF) in 2 patients (2.7\%). Measurement of LV systolic function showed a significant increase of the LV ejection fraction (Figure 1). LV ejection fraction was $38.9 \%$ on the first day, $51.6 \%$ on the $3^{\text {rd }}$ day $(p<0.05)$ and $55.8 \%$ on the $7^{\text {th }}$ day $(p<0.05)$.

Correlation analysis demonstrated a significant relation between the ST segment resolution velocity after reperfusion and LVEF on day 7 after PCI (Figure 2). The correlation coefficient was $r=0.53366(p<0.001)$. Statistical analysis included a univariate regression analysis with the use of a linear regression equation $[y=a+b x$; where $x-$ independent variable, $y$ - dependent variable, $a$ - constant, $b$ - regression index] to predict LVEF values based on the ST segment resolution velocity after reperfusion. In that case the linear regression equation was as follows: LVEF \% = $45.772+0.00233 \times$ ST segment resolution velocity $(\mu \mathrm{V} / \mathrm{h})$.

The coefficient of determination was $r^{2}=0.2848$ $(p<0.0001)$, which allows this regression model to be used for the prediction of events.

\section{Discussion}

It is known that angiographic indices of the infarct related artery patency are not sufficient for the assessment of the efficacy of reperfusion therapy in patients with ST-segment elevation myocardial infarction [1].

Many multicentre clinical trials dedicated to development of new schemes of reperfusion therapy have questioned the faith in the absolute relation between the coronary flow assessed by coronary angiography and the size of myocardial infarction [6-8].

Coronary angiography permits one to obtain a single shot picture showing patency of the coronary artery, but the IRA may become occluded once again in the postprocedural period.

Another limitation of coronary angiography is its inability to assess microvascular circulation, which determines the true myocardial perfusion. Microvascular circulation in the infarct zone may be impaired or completely abolished despite restoration of adequate flow 
in the infarct related artery. Evidence of the presence of the no-reflow phenomenon after thrombolytic treatment was found by Ito et al., who examined myocardial tissue perfusion using contrast echocardiography [9]. They found that approximately $25 \%$ of patients after successful opening of the coronary artery with restoration of TIMI 3 flow presented signs of the no-reflow phenomenon. Furthermore, a relation between no-reflow and progression of early left ventricular remodelling and heart failure was demonstrated [10]. Gąsior et al. determined the risk factors of microvascular flow and the no-reflow phenomenon in patients with STEMI treated with $\mathrm{PCI}$ [11].

Non-invasive criteria of successful coronary artery reperfusion include rapid chest pain resolution, occurrence of arrhythmia and conduction abnormalities, rapid resolution of pathological ECG changes (at first ST-segment resolution) and accelerated dynamics of myocardial necrosis marker changes.

Standard ECG registration and ECG Holter monitoring were included in the protocols of global multicentre studies. The GUSTO-I trial assessed the value of ECG Holter monitoring in the prediction of reperfusion. A criterion of TIMI flow 2 or 3 restoration was defined as more then 50\% ST-segment resolution in the most suitable lead $90 \mathrm{~min}$ after the procedure in comparison to baseline. It was assumed that the coronary artery undergoes reocclusion if ST-segment resolution does not reach $50 \%$ of the initial elevation or if initial resolution is replaced by new onset persistent elevation before coronary angiography [12].

Comparison of coronary artery patency $90 \mathrm{~min}$ and 180 min after the start of coronary angiography calculated on the basis of ST-segment dynamics demonstrated that the prognostic accuracy of this index is $74 \%$ for the diagnosis of TIMI flow 2 and 3 and 59\% for TIMI flow 0-1 (mean 70\%). Maximal and minimal sensitivity of this method was $92 \%$ and $75 \%$ respectively with $44-45 \%$ specificity. The accuracy of prognosis was independent from the localization of myocardial infarction.

An even more important issue is the prognostic value of ECG dynamics in terms of mortality of patients with myocardial infarction undergoing reperfusion. Besides the ISAM study, also the multicentre INJECT study compared the efficacy and safety of thrombolytic treatment in 1398 patients and demonstrated that the degree of initial ST-segment elevation resolution is a strong predictor of mortality during 35 days follow-up in STEMI [13]. Similar results were obtained in the GISSI-II, GUSTO-III and APEX-AMI studies $[14,15]$.

Interesting results were obtained during examination of ST-segment dynamic and survival of patients after myocardial infarction treated with primary $\mathrm{PCl}$. Frequency of 3-year survival after $\mathrm{PCI}$ with restoration of TIMI 3 flow was $71 \%$ in case of the lack of ST-segment resolution, $86 \%$ in case of ST-segment resolution of about $30-70 \%$ in comparison to the initial elevation and $96 \%$ in case of ST-segment resolution exceeding $70 \%$ of the initial elevation [5].

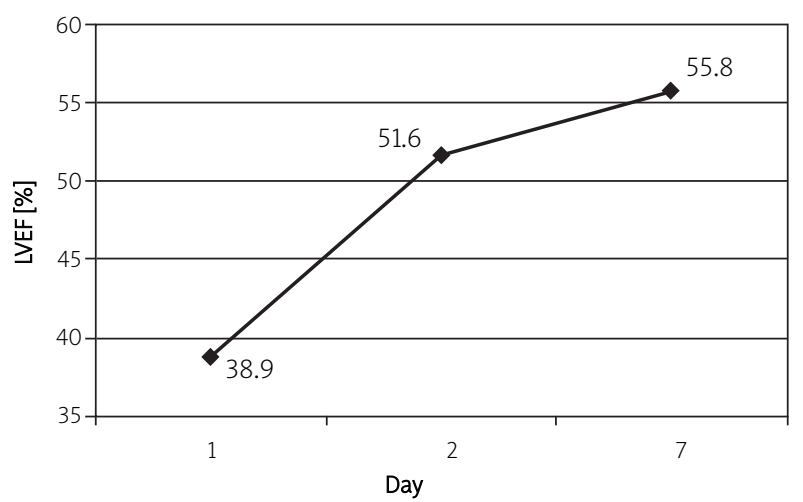

Fig. 1. Dynamics of left ventricular ejection fraction changes (LVEF) in the studied group

Ryc. 1. Dynamika wskaźnika frakcji wyrzutowej lewej komory (LVEF) w badanej grupie

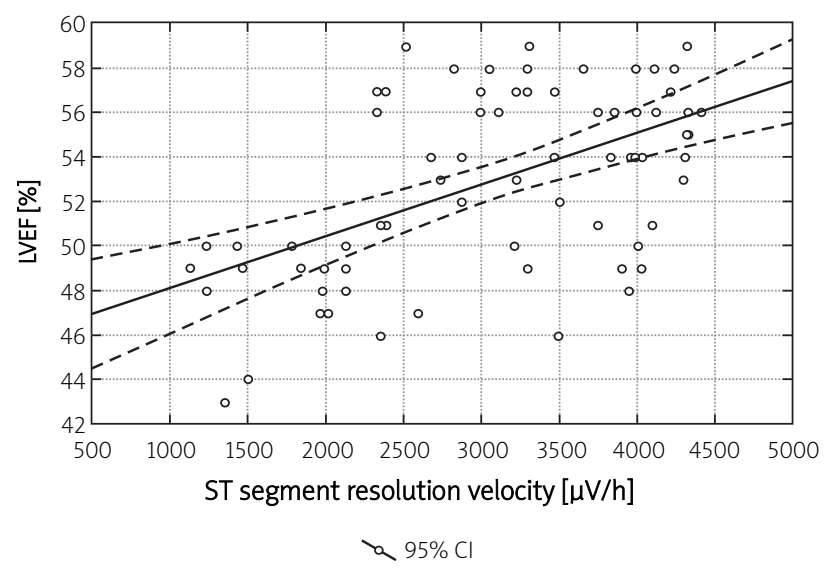

Fig. 2. Correlation between LVEF on day 7 and ST segment resolution velocity

Scatterplot: ST segment resolution velocity $(\mu \mathrm{V} / \mathrm{h})$ vs. LVEF (\%). $\operatorname{LVEF}(\%)=45.772+0.00233 \times$ ST segment resolution velocity $(\mu \mathrm{V} / \mathrm{h})$ Ryc. 2. Korelacja między wskaźnikami LVEF w 7. dniu i szybkością obniżenia odcinka ST

Scatterplot: szybkość obniżenia ST ( $\mu$ V/h) vs LVEF (\%).

$\operatorname{LVEF}(\%)=45,772+0,00233 \times$ szybkość obniżenia ST $(\mu \mathrm{V} / \mathrm{h})$

Survival of patients after myocardial infarction directly depends on LV systolic function and increases with improvement of LVEF.

Experimental studies have shown that restoration of mechanical function may be markedly delayed even in the case of coronary flow restoration after a short period of ischaemia and the lack of irreversible myocardial injury [1]. This phenomenon of reversible myocardial dysfunction after an ischaemic episode despite complete restoration of myocardial oxygen supply is known as stunning.

The state of myocardial stunning occurs clinically after early reperfusion of acute coronary artery occlusion in patients with acute coronary syndrome. Reduto et al. showed that LV ejection fraction does not increase directly after reperfusion, but after discharge from the hospital in patients after intracoronary administration of streptokinase 
[16]. Results obtained by other researchers [17] confirmed that regional LV function reliably increases not earlier than 10 days after successful thrombolytic treatment performed $5 \mathrm{~h}$ after the coronary artery occlusion.

Nanto et al. used contrast echocardiography to demonstrate late restoration of LV systolic function in patients after reperfusion. The study by these authors showed that 10 of the 21 patients had late restoration of LV function [18]. Similar conclusions were reached by Wita et al. in patients treated with primary percutaneous coronary intervention [19]. Our observations show that LV systolic function is restored 3-7 days after $\mathrm{PCl}$, which is related to the presence of myocardial stunning of the area supplied by the IRA. Our study sought to determine the relation between the ST-segment resolution velocity index after $\mathrm{PCI}$ (as a marker of successful myocardial perfusion restoration) and LVEF (as a marker of LV systolic function restoration).

The significant correlation between the indices of ST-segment resolution velocity after reperfusion and LVEF after 7 days allows one to predict the degree of LV systolic function restoration in the first hours of reperfusion.

The results confirm a high value of intraprocedural ECG monitoring for the assessment of reperfusion efficacy in patients with STEMI. These results demonstrate that ST-segment registration and analysis are necessary to assess the degree of adequate coronary artery flow restoration as well as short and long-term prognosis in patients with myocardial infarction undergoing percutaneous interventions.

\section{Conclusions}

1. Electrocardiogram monitoring has a high clinical value for the assessment of reperfusion efficacy in patients with ST-segment elevation myocardial infarction.

2. A significant correlation was found between the ST-segment resolution velocity after reperfusion and LVEF measured on day 7 after ST-segment elevation myocardial infarction.

3. ST-segment resolution velocity after reperfusion is a good predictor of LV systolic function restoration.

4. Percutaneous coronary intervention with stenting of the IRA is an effective method of reperfusion in patients with ST-segment elevation myocardial infarction.

\section{References}

1. Kloner RA, Ellis SG, Lange R, Braunwald E. Studies of experimental coronary artery reperfusion effects of infarct size, myocardial function, biochemistry, ultrastructure and microvascular damage. Circulation 1983; 68 Suppl. 1: 8-15.

2. Braunwald E. Myocardial reperfusion limitation of infarct size, reduction of left ventricular dysfunction and improved survival. Should the paradigm be expanded? Circulation 1989; 79: 441-444.

3. Pawłowska-Jenerowicz W, Lechowicz W, Dąbrowski M. Favourable impact of acute myocardial infarction treatment by percutaneous coronary intervention on cardiovascular efficiency during oneyear observation. Post Kardiol Interw 2006; 2: 199-206.
4. Wijns W, Kolh P, Danchin N, et al. Wytyczne dotyczące rewaskularyzacji mięśnia sercowego. Kardiol Pol 2010; 68 supl. VIII: 569-638.

5. Van't Hof AWJ, Liem A, de Boer MJ, et al. Clinical value of 12-lead electrocardiogram after successful reperfusion therapy for acute myocardial infarction. Lancet 1997; 350: 615-619.

6. Bleich SD, Adgey AAJ, Pickering E, et al. An angiographic assessment of the efficacy and safety of front-loaded and bolus regimen of activase (alteplase, recombinant): the Double-Bolus Lytic Efficacy Trial (The DouBLE Trial). Circulation 1995; 92 (Suppl. I): 1-415 (abstract).

7. Purvis JA, McNeill AJ, Siddiqui RA, et al. Efficacy of $100 \mathrm{mg}$ doublebolus alteplase in achieving complete perfusion in the treatment of acute myocardial infarction. J Amer Coll Cardiol 1994; 23: 6-10.

8. The Continuous Infusion versus Double-Bolus Administration of Alteplase (COBALT) Investigators. A comparison of continuous infusion of alteplase with double-bolus administration for acute myocardial infarction. N Engl J Med 1997; 337: 1124-1130.

9. Ito H, Maruyama A, Iwakura K, et al. Clinical implication of the "no-reflow" phenomenon. A predictor of complication and left ventricular remodeling in reperfused anterior wall myocardial infarction. Circulation 1996; 93: 223-228.

10. Ito H, Maruyama A, Iwakura K, et al. Clinical implication of the "no-reflow" phenomenon. A predictor of complication and left ventricular remodeling in reperfused anterior wall myocardial infarction. Circulation 1996; 93: 223-228.

11. Gąsior M, Pres D, Gierlotka M, et al. Factors affecting microvascular flow in patients with myocardial infarction treated with percutaneous coronary intervention. Post Kardiol Interw 2007; 3: 121-127.

12. Langer A, Krucoff MW, Klootwijk P, et al. Noninvasive assessment of speed and stability of infarct-related artery reperfusion: results of the GUSTO ST segment monitoring study. Global Utilization of Streptokinase and Tissue Plasminogen Activator for Occluded Coronary Arteries. J Am Coll Cardiol 1995; 25: 1552-1557.

13. Schroder R, Wegscheider K, Schroder K, et al. Extent of early ST segment elevation resolution: a strong predictor of outcome in patients with acute myocardial infarction and a sensitive measure to compare thrombolytic regimens - A substudy of the International Joint Efficacy Comparison of Thrombolysis (INJECT) trial. J Am Coll Cardiol 1995; 26: 1657-1664.

14. White HD, Braunwald E. Applying the open artery theory: use of predictive survival markers. Eur Heart J 1998; 19: 1132-1139.

15. Buller CE, Fu Y, Mahaffey KW, et al. ST-segment recovery and outcome after primary percutaneous coronary intervention for STelevation myocardial infarction: insights from the assessment of pexelizumab in acute myocardial infarction (APEX-AMI) trial. Circulation 2008; 118: 1335-1346.

16. Reduto LA, Smalling RW, Freund GG, et al. Intracoronary infusion of streptokinase in patients with acute myocardial infarction: Effects of reperfusion on left ventricular performance. Am J Cardiol 1981; 48: 403-409.

17. Go RT, Maclntyre WJ, Chen EQ, et al. Current status of the clinical applications of cardiac positron emission tomography. Radiol Clin North Am 1994; 32: 501-519.

18. Nanto S, Lim YJ, Masuyama T, et al. Diagnostic stunned myocardium with contrast echocardiography. J Am Soc Echocardiogr 1996; 9: 314-319.

19. Wita K, Filipecki A, Węglarz P, et al. Prediction of left ventricular remodelling in patients with acute myocardial infarction treated with primary percutaneous coronary intervention (prediction of remodelling). Post Kardiol Interw 2005; 1: 86-96. 